\title{
Relationship Between Religion and the Arts and Cultural Management Perspective
}

\author{
Edalat Nemati, Sorour Robatjazi, Sima Haghnazari \\ Technical and Vocational University, Tehran, Iran
}

\begin{abstract}
Phenomenon of "art" in human history has been one of the finest expressions of human life, because in a sense, the art of the leakage is the beauty of the human spirit. The arts and artists always have a great importance in societies. The importance of the art is rooted in people’s inclination of "beautiful friendship” between human and nature. Art, as the spirit of human life, has a wide link with all its vital organs and manifestations such as faith, culture, civilization, technology, and any other aspects of human life. Normal growth and development of human thinking have caused changes in the content and basis of human life, then culture arises. Cultural developments in scientific and technological advances of today's high speed are outstanding; as in all areas of the superstructure and infrastructure indigenous culture has been subject to change. It is important for the cultural authorities. The authors in this paper review the existing cultural manifestations to achieve an overall analysis on the subject.
\end{abstract}

Keywords: religion, the arts, administration, management of culture

\section{Introduction}

Every nation has some forms of religious belief and religious belief is independent. Ways of life and spiritual practices of people all over the world are the basis of religious belief. So faith is part of human identity. This means that religion or belief will constitute one of the pillars of the national culture of any nation. Religions without full knowledge and understanding "cultural identity" are not allowed. Europeans today have Christianity, Islam, Shia Iranians; Indians have Hinduism, Buddhism; and Chinese... It is known that religion, art and human culture are compatible. Most forms of "art" are manifested in religious issues, because both of these phenomena are the related spiritual realm. The close relationship of religion (especially religions) and promoted, century in the form of "embodied spirituality", "spiritual manifestation in space and worship space", "symbolic ritual religious" and "religious symbols" has been manifested.

Basically you should know the art (whether religious or non-religious) is "attractive and effective expression of ideas and a worldview and a school of thought”. The art of modern secular culture is a relatively new phenomenon to fit the secular attitude that culture is emerging, but it is also a form of self-expression.

\section{Methods}

The method used in this study is during the literature review and data related to the concept of religion, the concept of art and the relationship between religion and art in various communities are collected using existing

Edalat Nemati, lecturer, Ph.D., SHamsipoor Technical and Vocational College, Technical and Vocational University.

Sorour Robatjazi, master, dean of Student Administration Sevice, Technical and Vocational University.

Sima Haghnazari, lecturer, Ph.D., Technical and Vocational University. 
databases and address books and articles.

\section{The Concept of Culture}

Culture has several meanings in Persian. Culture is a term that has different definitions.

Persian culture specific, culture is composed of two words mean the oven and Hong literature, education, science, knowledge, wisdom and culture has defined.

"Culture" is a Persian word that has two components of "FAR" mean the (Shan and times) and "Hong Kong" means (heavy) emerged. Thus, it means "weighty dignity" that is. Some of the "Frhnj" knowledge of science and literature means that (Dehkhoda).

The word "culture” in Persian literature has several meanings, including men of good manners, politeness, education, knowledge, knowledge of customs, a collection of folk arts, and applied sciences.

\section{Concept of Cultural Management}

After the era of specialization and division of knowledge into disciplines and branches numerous times now integrated with each other and the emergence of interdisciplinary science in come, as we see every day, several academic disciplines in the university and prestigious and world famous Academy, developed and taught the seats are held by. As you study, "Human and Economic Geography” integrated science of geography, anthropology and economics emerged in the specific issues common to all sciences are discussed. But the emergence of this kind of motivation, and lack of social scientific opinion is that the proportion of independent of high performance, charm and also receive.

Cultural Management (science is one of the types of management science and culture of the sciences, such as sociology, history, psychology, anthropology, politics and so on) has come into existence. The scientific discipline of not more than a few years of Management Science, Faculty Chair of the University has been accredited. The goal of this discipline, leadership training, management and governance environment that is capable and cultural organizations, the organizations and institutions such as radio, television, universities, schools, cultural centers, houses of culture, Institute of culture and media, News, press, educational institution, art school, exhibition centers, museums, gallery management, cultural ministries organizations, organizations publishing Institute of Promotional, public libraries and so on. The academic discipline of all field activities for alumni, reflect the social needs of the community. This is a gap that must be addressed by the designers of this course and its graduates.

Because of the pillars of social identity a society is, its management requires specific skills liberal arts is as cultural managers must also have knowledge of management, psychology, sociology, principles of education, philosophy, history, art and literature are also considerable data to benefit from all the know and the ability to draw acceptable in their cultural universals, their ability to be the appropriate solution for steering the organization's culture, organization or institution under its management or design to choose. It should be noted that the cultural realm organizations and their managers, are far more extensive and sensitive organizations other than active in the community. Because the intended audience cultural activities in all walks of life, the diversity of the audience than other activities, wait is over. This leads to three important issues for managers concerned with culture as the most important thing to be considered. First, because of his activities, has a varied audience, programs and activities such a culture should be designed and implemented to the taste of all classes of society children, adolescents, young adults, middle-aged and elderly, is consistent, the issue of cultural 
distance between generations Jvamh current is high, the more difficult it is. Secondly, a successful manager must have a clear understanding of the culture and the cultural changes in society, while trying to manage these changes, try to be a perfect harmony between work cultural institution under the management of their own, these developments provide to the changes to contain and maintain and even increase the audience. Thirdly, the existence of sensitive culture and related social, environmental and political sensitivity-widespread social for managers who are working in this area to develop, very carefully and cautiously leading cultural organizations paid. However, in the implementation of the unintentional cause a slow, fleeing heavy responsibility, away from the hard dangerous (risk) and 10 other managerial weaknesses that with Wisdom and understanding power, they can be avoided. It says one of the experts in this field in the absence of constant change and instability, cultural management to acrobatics height of 200 meters metaphor the success of the highly acclaimed campaign and the slightest mistake, it coincides with the end of the regular work. Furthermore, this profile is a formidable director. To obtain an understanding of management science, cultural, inevitably has to explain its two components, namely, "knowledge management" and the category "culture" and pay close attention to issues of recognizing it.

\section{The Concept of Religion}

1-religious meaning in the word of righteousness, obedience, reward, routine, arithmetic, Kish, virtue and... By Islamic scholars and notice about it is that the examples cited are:

(1) Religion is a set of beliefs and values are based on the beliefs, values, common sense rules of religion and morality and virtue, and the minutiae ego takes over. The first part of the definition of religion, thought and theoretical aspects related to (grand master of modern Arabic-Farsi).

(2) Means of religion is a set of religious beliefs, ethics and enforcement of laws and regulations and the objectives that guided the man is happy. Religion in this sense is twofold: religion, human, and divine religion.

All the rules go something like profit and not force him. Be free from obligation and responsibility, and the reaction against divine religion and achievements, including the approach to religion (Sura M, verse 70).

Divine religion: beliefs, moral and practical rules for the guidance of the Lord it up in the light of its teachings, their true freedom to control your whim. He needs to pay attention to the fact that the human and divine religion and a complete and comprehensive program provides closed. All is expected of him, Mohammad Taghi Mesbah Yazdi, the realm of religion, of speech, of religion Forums.

\section{Concept of Art}

"Art" of social phenomena are pervasive in human societies. With an overview of the history of human culture, which can be downloaded "art" is one of the fundamental issues of human life. Telling the truth (art) with a direct relationship to the spiritual realm it to explain the spiritual aspects of his work are inseparable. Artistic manifestations of the long-form Vashkal cryptic symbols, signs a contract as the facts are Ultra natural, human life. There has been fixed. The presence of the man primitive and the modern civilized man, as Mazaheri sacred, respected and well.

"Art" is a term Nations language and literature, particularly in the English language, has been used to mean different things, such as knowledge, wisdom, knowledge, grace, virtue, integrity, intelligence, and subtlety of human... Arts humans have selected for your comfort. What artists and audiences, in a work of art, support peace-seeking, the happiness and sweetness to the soul. The origin of the sweetness of the art means 
"beauty" is. Although the size of the concept of beauty is art, but it is impossible for the human mind is all too familiar. Although it is a beautiful work of art as something appealing to his audience to absorb-to. The ANSA but the beauty is perceived in different—but in part because they all have in common.

However, the concept of fine art does not help to explain it better not. Rather, it is the art of the root cause of spiritual and human emotions, a person must be clarified. As a work of art and what is said about it is that can distinguish "the art, transport sensationalism artist is no longer human". Narrow artists, their works have been able, emotions and experiences can reveal itself as a way to convey their feelings they provoke feelings of cholera contacts are also shared with the audience's emotions, relationship and spiritual bond with them to establish. Artists novel works, what ordinary people have failed to understand it, for everyone who understands. Photography, painting, sculpture, music composition, film, theater, architecture, design, cartoon, and now the rest of human life are considered stable and attractive.

\section{Relationship Between Art and Religion}

Phenomena of religion, art, and human culture are compatible. With an overview of the history of art in human culture can be downloaded greatest manifestations of "art" in history, who works on issues of religion and faith is manifested. This is perhaps because he basically found "religion" and "art", the two basic issues of human life are the spiritual realm are concerned. Although these are two of a kind, but they account for the human and spiritual aspects of his work are inseparable. Artistic manifestations in the form of cryptic symbols and shapes as conventional signs of supernatural facts are in life- there have been constant. The presence of the man primitive and the modern civilized man, as Mazaheri sacred, respected and well.

The feeding of the principles and concepts of the art of spiritual religion has grown. Since it is a kind of art, beauty and beauty is spiritual shown himself away from the ugliness and evil and the evil of his decorated, as religious art, mainly glory and holiness is inherent effects. The close relationship of religion (especially religions) and promoted, from the facts that can be derived from they can be expressed in several categories.

This regulation, the current values of life time (such as his crucifixion and Christians) and sometimes periodically (i.e., Hajj) and particular time be hold, but in any case the secret of Broadcasting password, the action associated with religious beliefs and religious expression, religion plays an important role in preparing for the sacred sense of interdependence and collective needs of the Almighty (Allah) are.

Art techniques and tools here to help Dean and his followers in a spiritual atmosphere and feeling of the sublime and glorious is fascinates.

As the main feeder of the arts, the culture and the role are different. Any scholar with a little attention can easily sample manifestations of religious influence on the arts, such as music, poetry, drama, architecture, painting, sculpture and masonry.

\section{Religious Symbols and Art}

In terms of religious faith sometimes means "overlay" (color) is used. The overlay typically refers to a subjective coloring stained it a special identity to adherents of other religions are distinct. Art category according to the same rule, if its formation based on religious values, color, religion, self-identity and the fact that his office shall, as agent of religious identity, the role of to. This two-way interaction, the importance of the relationship between art and religion is well established that. Schwann (1383) says in this regard: 
cannot be unless manifests in different forms and shapes. If properties (followers) need further explanation and interpretation of Scripture to the art (and vice versa), most people need more to art than to ruling and mystical beliefs, and since the class properties (members) of corporeal The community depends, indirectly they need to have art.

\section{Religious and Secular Art}

This definition more than anything the human mind towards religion leads to. This approach to art, "religious art" to explain. The art of every religion has its own special features.

Today, the art of "Hnrdyny" and "secular art" is separate. Maybe we were in past ages but never found secular societies of the art for such art, valued not distinguish official said. Secular art and culture in the modern secular world has emerged in the past few centuries, phenomenon is relatively new. After "Rnsas", worldly life and the human mind prevailed over concepts, symbols art to fit the secular attitude gradually emerged and were defined as multiple branches. In fact, over blasphemy and idolatry, as reflection on human nature and the world overcoming his art, as appropriate, in the thinking and worldview of secular and religious art that once used to explain spiritual truth go and seek spiritual beauty of it was, the dress became an understatement. Thus, over the secular world, as humans, beauty, love, beauty and appearance of the world is realized, the fund focuses on contemporary art and everything that is worldly, the propagation. The non-religious aspects of art, rather than the amount are allowed by the fact that human vision is introduced.

This expression cannot the same as the religious and secular art, because art is a form of art based on religious beliefs arising from non-religious worldviews are very different in form and substance. Therefore, a distinction should be made on the evaluation forms and be separated from them.

\section{Conclusion}

They called them religious artists. People believe that there is a consensus about individuals and humanity, religious and secular art, however, about the content of religious art should be, some of them do not engage in religious and secular art. Islamic scholars believe that every religion has an art form and manner and also appearance. Divine creation of any religious code provides the allegorical language, and Islamic art encryption and expression of a religious belief in the spiritual worlds. The spiritual world is the visible image of the religious art that has always made sense. Religion can also promote the growth of art, art can provide spiritual values and religious norms, and can have a major effect. Through the interaction of the two strains, expression of the arts will be endowed with a religious character. Due to the wide variety of religions and issues of each of them and the other arts, people should debate and talk about all the features of Mysore religious art, but examples of religious art should not be cited.

\section{References}

Amoli, A. J. (1389). Man vs religion (pp. 24-27). Tehran: Fanoos.

Amoli, A. J. (1391). Art, beauty, perspective, religion. Ghom: Islami.

Cha, A. M. (1357). Holy and unholy (N. Zngvyy, Trans.). Tehran: Soroush.

Cha, A. M. (1376). Essays on religion (J. Sattari, Trans.). Tehran: Soroush.

Copleston, F. (1387). History of philosophy (J. Divine, Trans.). Tehran: Wisdom.

Dehkhoda, M. (1377). Dehkhoda dictionary. Tehran: Tehran University Institute of Publishing and Printing.

Jafari, M. (1375). Beauty and art of Islam. Tehran: Samt.

Khosropanah, A. (1390). New words (p. 335). Tehran: Nasir.

Mahmoud. (1372). God's sake, general philosophy insurance. Tehran: Iran.

Moin, M. (1371). Persian culture specific. Tehran: Amir Kabir. 
Nagi, M. (1379a). And economic interaction of traditional and modern art. Religious Art Magazine, (6).

Nagi, M. (1379b). Not spiritual roots of art. Journal of Artistic Research Center of the Ministry of Culture and Islamic Guidance, 46, 79-80.

Nagizadeh, M. (1379). “The Role of the Mosque of Islamic identity” concept and quality far more space. Art Letter, 2, 50-54.

Sattari, J. (1369). Translation of sacred art. Tehran: Soroush.

Schwann, F. H. (1383). Principles and norms of international art (S. H. Nasr, Trans.). In The Spiritual Foundations of Art (pp. 72-75).

Tolstoy, L. (1373). What is art (K. Farmer, Trans.). Tehran: Amir Kabir.

Yafh, M. L. (1385). Karl Gvstavyvng: Man and his symbols. Tehran: Toos. 